\title{
De los delitos contra los derechos de autor en el Código Penal colombiano*
}

\author{
Juan Carlos Álvarez Álvarez ${ }^{* *}$ \\ María Adelaida Ceballos Bedoya** \\ Álvaro Mauricio Muñoz Sierra***
}

\section{Resumen}

Los derechos de propiedad intelectual comprenden los derechos de autor, el derecho de propiedad industrial y el derecho sobre descubrimientos científicos y demás. De allí que en nuestro código penal se encuentren, por un lado, normas protectoras de marcas y patentes (art 306 C.P.); y, por otro, normas relativas a la protección de los derechos de autor (arts. 270 a 272 C.P.). Dentro de estos últimos a su vez se encuentran los derechos de autor en sentido estricto y los derechos conexos o afines: el objeto material en los primeros recae sobre la obra literaria, artística, científica, entre otros.; mientras en los segundos recae sobre la interpretación o ejecución artística de una obra literaria,

\footnotetext{
* El presente artículo es resultado del proyecto de investigación financiado por la Universidad EAFIT, Dirección de investigación, titulado "La protección jurídico-penal de la propiedad intelectual: estudio de los tipos penales relativos a los derechos de autor en el código penal colombiano", realizado durante el año 2007 bajo el código interno 13-0060.

**Profesor Universidad EAFIT, Medellín, Colombia. Contacto: jalvar39@eafit.edu.co

***Profesora Universidad EAFIT, Medellín, Colombia. Contacto: mceball3@eafit.edu.co

****Juez Promiscuo Municipal. Contacto: mauro23_1@hotmail.com
} 
94 De los delitos contra los derechos de autor en el Código Penal colombiano - Juan Carlos Álvarez Álvarez,

María Adelaida Ceballos Bedoya y Álvaro Mauricio Muñoz Sierra

artística o científica, fonogramas, videogramas y emisiones. La propuesta que aquí se desarrollará es que al momento de interpretar y aplicar estos tipos penales se exija, primero, un ánimo de lucro al autor de la conducta y, segundo, un perjuicio concreto a un tercero. Aceptar esta propuesta no sólo permitirá limitar el tipo penal, sino que también reforzará la protección del elemento patrimonial.

\section{Palabras clave}

Derechos de autor y derechos conexos, derechos patrimoniales, derechos morales, bienes jurídicos supraindividuales, monismo, dualismo.

\section{Abstract}

Intellectual property rights include those of copyright, industrial property, scientific discoveries, among others. In our criminal code there are rules that protect trademarks and patents (article 306) and rules that protect copyright (arts. 270 to 272). Within copyright there is a division between the copyright stricto sensu and the protection of related rights. While the material object in copyright stricto sensu is the literary, artistic or scientific work, in related rights is the interpretation or execution of those works. Our proposal is to include within the criminal definition the requirement of a profit-making conduct plus a concrete damage to a third person. This proposal will not only limit the criminal definition, but it will also reinforce the protection of the patrimonial dimension.

\section{Keywords}

Author's rights, copyright, related rights, patrimonial rights, moral rights, monism, dualism, supra-individual legal interests..

\section{Sumario}

1. Propiedad intelectual y derechos de autor; 2. Derecho de autor y derechos conexos; 3. Objeto sobre el cual recae la protección; 4 . Derechos morales y derechos patrimoniales; 4.1. Derechos morales; 4.2. Derechos patrimoniales; 5 . Bien jurídico: ¿individual o colectivo?; 6. Algunos aspectos relevantes relacionados con la interpretación de los artículos 270 y 271; 6.1. Artículo 270; 6.2 Artículo 271; 7. Relación entre las vertientes del derecho de autor y los artículos 270 y 271 del código penal; 8. Propuesta de unificación de la regulación penal. 


\section{Propiedad intelectual y derechos de autor}

Los bienes inmateriales que resultan de creaciones del intelecto han sido agrupados, para efectos jurídicos, en el concepto de derechos propiedad intelectual. A través de este concepto se procura, por un lado, proteger, respaldar y recompensar al creador ${ }^{1}$ y a su creación; y, por otro lado, se busca regular la competencia entre productores, haya o no creación de por medio².

Tanto en la doctrina como en los convenios internacionales suele entenderse que los derechos de propiedad intelectual comprenden los derechos de autor, los derechos de propiedad industrial y los derechos sobre descubrimientos científicos, además de muchas otras creaciones posibles de que es capaz el ser humano. Siguiendo esta misma tendencia, también la Constitución Política de 1991, en su artículo 61, optó por hacer referencia, también de manera genérica, a la propiedad intelectual, sin distingo de la protección que merecieran los derechos de autor y la propiedad industrial consideradas de manera independiente ${ }^{3}$.

No obstante lo anterior, en el código penal colombiano (ley 599 de 2000), el legislador sí optó por un tratamiento diferenciado entre las dos señaladas categorías, pertenecientes a la propiedad intelectual ${ }^{4}$. Es por ello que se encuentran, de una parte, normas protectoras de marcas y patentes (artículo 306 C.P.5); $y$, de otra parte, normas relativas específicamente a la protección de los derechos de autor (arts. 270 a 272

1 Se podrá destacar adicionalmente sobre el derecho de propiedad intelectual, como lo ha hecho la Corte Constitucional, que el mismo no sólo se fundamenta en derechos como el libre desarrollo de la personalidad, de la libertad de expresión y el derecho al reconocimiento del trabajo individual, sino también en otros derechos que van más allá de la esfera de los derechos subjetivos pero con los que tiene una estrecha relación, entre los que nosotros destacamos el reconocimiento del pluralismo (art. $1{ }^{\circ}$ C.N) y de la diversidad cultural (Art. 7). Corte Constitucional, sentencia C-118 de 1995, MP. Clara Inés Vargas Hernández.

2 Delia Lipszyc, Derecho de Autor y derechos conexos, Ediciones Unesco, Cerlalc, 1993, citada en Corte Constitucional, sentencia C- 276 de 1996, MP, Julio César Ortiz Gutiérrez.

3 Artículo 61 C.N.: "El Estado protegerá la propiedad intelectual, por el tiempo y mediante las formalidades que establezca la ley".

4 Sobre el particular véase Vicente E Gaviria Londoño, "Delitos contra los derechos de autor", en Lecciones de derecho penal. Parte especial, Bogotá, Universidad Externado de Colombia, 2.003, p. 533, quien critica la distinción en la legislación colombiana: "Así las cosas, no existe fundamento científico ni mucho menos jurídico para que se mantenga un estudio y tratamiento separado -como acontece con el Código Penal colombiano-, entre los conceptos de propiedad industrial y derechos de autor, ya que la razón de ser de la protección en ambos caos es, en esencia, la creación intelectual".

5 Artículo 306 C.P..: "El que utilice fraudulentamente nombre comercial, enseña, marca, patente de invención, modelo de utilidad o diseño industrial protegido legalmente o similarmente confundible con uno protegido legalmente, incurrirá en prisión de dos(2) a cuatro(4) años y multa de veinte(20) a dos mil (2.000) salarios mínimos legales mensuales vigentes.

En la misma pena incurrirá quien financie, suministre, distribuya, ponga en venta, comercialice, transporte 0 adquiera con fines comerciales 0 de intermediación, bienes producidos 0 distribuidos en las circunstancias previstas en el inciso anterior". 
C.P.). El presente escrito se referirá a este último grupo de normas, limitándose a analizar específicamente los artículos 270 y 271 del código penal ${ }^{6}$.

\section{Derecho de autor y derechos conexos}

Los derechos de autor hacen parte de los derechos de segunda generación (derechos sociales, culturales y económicos) y traen consigo un conjunto de facultades y derechos para el creador de una obra. Se refiere a una forma de propiedad privada que reconoce una protección jurídica especial, para empezar, al creador o creadores de una obra del intelecto, como es el caso de las obras artísticas, literarias, científicas, entre otros. Esta protección que recae sobre el autor como persona natural se enmarcaría en los derechos de autor en sentido estricto.

$6 \quad$ Artículo 270 C.P.: "Incurrirá en prisión de dos (2) a cinco (5) años y multa de veinte (20) a doscientos (200) salarios mínimos legales mensuales vigentes quien:

1. Publique, total o parcialmente, sin autorización previa y expresa del titular del derecho, una obra inédita de carácter literario, artístico, científico, cinematográfico, audiovisual o fonograma, programa de ordenador o soporte lógico.

2. Inscriba en el registro de autor con nombre de persona distinta del autor verdadero, o con título cambiado o suprimido, 0 con el texto alterado, deformado, modificado o mutilado, o mencionando falsamente el nombre del editor o productor de una obra de carácter literario, artístico, científico, audiovisual o fonograma, programa de ordenador 0 soporte lógico.

3. Por cualquier medio o procedimiento compendie, mutile 0 transforme, sin autorización previa 0 expresa de su titular, una obra de carácter literario, artístico, científico, audiovisual o fonograma, programa de ordenador o soporte lógico.

\section{Parágrafo}

Si en el soporte material, carátula o presentación de una obra de carácter literario, artístico, científico, fonograma, videograma, programa de ordenador o soporte lógico, u obra cinematográfica se emplea el nombre, razón social, logotipo o distintivo del titular legítimo del derecho, en los casos de cambio, supresión, alteración, modificación o mutilación del título o del texto de la obra, las penas anteriores se aumentarán hasta en la mitad.

Artículo 271 C.P.: "Violación a los derechos patrimoniales de autor y derechos conexos. Modificado por la Ley 1032 de 2006. Incurrirá en prisión de cuatro (4) a ocho (8) años y multa de veintiséis punto sesenta y seis (26.66) a mil (1.000) salarios mínimos legales mensuales vigentes quien, salvo las excepciones previstas en la ley, sin autorización previa y expresa del titular de los derechos correspondientes:

1. Por cualquier medio o procedimiento, reproduzca una obra de carácter literario, científico, artístico o cinematográfico, fonograma, videograma, soporte lógico o programa de ordenador, o, quien transporte, almacene, conserve, distribuya, importe, venda, ofrezca, adquiera para la venta 0 distribución, o suministre a cualquier título dichas reproducciones.

2. Represente, ejecute o exhiba públicamente obras teatrales, musicales, fonogramas, videogramas, obras cinematográficas, o cualquier otra obra de carácter literario 0 artístico.

3. Alquile 0 , de cualquier otro modo, comercialice fonogramas, videogramas, programas de ordenador o soportes lógicos u obras cinematográficas.

4. Fije, reproduzca o comercialice las representaciones públicas de obras teatrales o musicales.

5. Disponga, realice o utilice, por cualquier medio o procedimiento, la comunicación, fijación, ejecución, exhibición, comercialización, difusión o distribución y representación de una obra de las protegidas en este título.

6. Retransmita, fije, reproduzca o, por cualquier medio sonoro o audiovisual, divulgue las emisiones de los organismos de radiodifusión. Recepcione, difunda o distribuya por cualquier medio las emisiones de la televisión por suscripción". 
Por su parte, la protección que recae sobre aquellos que han participado en otras etapas de la obra, aunque no en su creación, haría parte de los derechos conexos o afines. Por tanto, se protegen tanto los derechos de quien originalmente crea la nueva obra del intelecto como de quienes la divulgan, ejecutan, interpretan y producen. Al respecto Rengifo García señala "En virtud de la Convención de Roma del 26 de octubre de 1991, adoptada por nuestro ordenamiento jurídico a través de la Ley 48 de 1975, se le otorgó protección a los llamados derechos conexos, esto es, aquellos referidos a las personas que si bien no participan en la creación, sí intervienen en la difusión de las obras literarias y artísticas, como los artistas intérpretes o ejecutantes, los productores de fonogramas y los organismos de radiodifusión. Los artistas intérpretes 0 ejecutantes disfrutan, como los autores, además de derechos patrimoniales, de derechos morales"7.

Según la Corte Constitucional "(...), la razón de ser del derecho de los artistas, intérpretes y ejecutantes, debe buscarse en la existencia de una creatividad semejante a la que realiza el autor, porque sin duda, el artista da a su interpretación un toque personal y creativo"8. A los productores, al parecer, se los protegería tan sólo por su estrecha vinculación con la obra y en la medida en que a ellos se les cause un perjuicio, también y como consecuencia, se puede afectar al creador.

No obstante, es importante precisar que el autor (en sentido estricto) es el titular originario de los derechos morales y patrimoniales reconocidos por la ley, y no gozarán de protección aquellos aportes puramente físicos 0 aquellas ideas que hayan sido un mero antecedente de la creación, pues quien realiza este tipo de aportes no goza de la condición de autor ${ }^{9}$.

\section{Objeto sobre el cual recae protección}

Cuando en el marco de la discusión sobre los derechos de autor se acude a expresiones como "creación intelectual", "obra del intelecto" u otras denominaciones de similar significado, se pretende hacer referencia a toda posible expresión original de la inteligencia de una persona que se manifieste de forma perceptible. Ello quiere decir que se parte del presupuesto de que se trata de creaciones que han sido exteriorizadas (imágenes, textos, partituras, entre otros.); es decir, que no hacen parte exclusivamente del fuero interno del creador. Ello no quiere decir, sin embargo, que la protección propia de los derechos de autor recaiga en la obra materializada o exteriorizada como tal, como objeto físico.

7 Ernesto Rengifo García, Propiedad intelectual. El moderno derecho de autor, Bogotá, Universidad Externado de Colombia, 1997, pp.150-151.

8 Corte Constitucional, sentencia C-118 de 1995, MP. Clara Inés Vargas Hernández.

9 Véase el concepto que al respecto brinda la Dirección Nacional de Derecho de Autor; que, aunque no vinculante jurídicamente, puede servir de guía al intérprete. http://www.derautor.gov.co/htm/ preguntas.htm. Consultado el 10 de diciembre de 2007. 
Dicho de otro modo, con los derechos de autor (en general con la propiedad intelectual) lo que pretende protegerse es la creación, el bien inmaterial, no los medios materiales a través de los cuales se expresa, se manifiesta o se deja constancia de la creación (lienzo, mármol, soporte magnético, entre otros), puesto que estos medios reciben su correspondiente protección a través de los derechos de propiedad ordinaria y los demás derechos que recaen sobre bienes materiales ${ }^{10}$.

No obstante, en ocasiones se podrán presentar conductas que resulten lesivas de los derechos de autor tanto en relación con el bien material como con el inmaterial. Por ejemplo, cuando el código penal sanciona la transformación de la obra sin autorización del titular del derecho, se refiere a la modificación de la idea más que a la materialidad en que se encuentra la misma; mientras que cuando el mismo código sanciona el alquilar la obra sin autorización del titular, la conducta ha recaído propiamente sobre el bien material en que se encuentra la creación.

De acuerdo con lo anterior, se encuentra que cuando los artículos 270 y 271 del código penal aluden a ciertas obras o creaciones sobre las que recaerá la conducta, ello bien podrá referirse al bien material o inmaterial, mas tras ello se encontrará siempre la creación intelectual (o el derecho afín a ella), que es precisamente la que da lugar a que la materialidad exista. Las creaciones intelectuales específicamente incluidas en la regulación penal colombiana son: las obras de carácter literario, artístico, científico, cinematográfico, audiovisual, los fonogramas, videogramas, programas de ordenador o soportes lógicos (software) y las emisiones de los organismos de radiodifusión¹.

Cabe anotar que lo que puede entenderse por obra o creación intelectual no se agota en el listado taxativo que trae el código penal, ya que son muchas las formas y los medios en los que se pueden manifestar la inteligencia y creatividad de las personas.

La Corte Constitucional brinda al respecto la siguiente definición general:

\begin{abstract}
El objeto que se protege a través del derecho de autor es la obra, esto es "...la expresión personal de la inteligencia que desarrolla un pensamiento que se manifiesta bajo una forma perceptible, tiene originalidad o individualidad suficiente, y es apta para ser difundida y reproducida". Dicha protección está condicionada al cumplimiento de los siguientes presupuestos: el derecho de autor protege las creaciones formales no las ideas; la originalidad es condición necesaria para la protección; ella, además, no
\end{abstract}

10 Véase Miguel Bajo Fernández/Silvina Bacigalupo, Derecho penal económico, Madrid, Editorial Centro de Estudios Ramón Areces, S.A, 2.001, pp. 436 y 437. Estos autores expresamente señalan que "no hay que confundir el derecho de autor con el derecho de propiedad sobre el corpus mechanicum que puede regularse de forma completamente independiente" (p.437) También, Juan José González Rus, "Bien jurídico protegido en los delitos contra la propiedad intelectual", en El nuevo código penal: presupuestos y fundamentos. Libro homenaje al Profesor Doctor Don Ángel Torío López, Granada, 1.999, pp. 771-772. Este último autor pone de presente que "las distinciones expuestas tienen gran trascendencia a la hora de delimitar las modalidades delictivas aplicables, en función de los derechos y sujetos afectados, cuestión directamente relacionada con los concursos de delitos" (p.772) 
depende del valor o mérito de la obra, ni de su destino o forma de expresión y, en la mayoría de legislaciones, no está sujeta al cumplimiento de formalidades; $(. . .)^{12}$.

De otro lado, conviene también resaltar que la referencia a los derechos de autor en un sentido amplio, incluye también los denominados derechos conexos, los cuales se refieren, como ya se indicó a los que tiene aquellos que no participan en la creación de la obra como lo son los intérpretes o ejecutantes y los productores de fonogramas y los organismos de radiodifusión.

\section{Derechos de autor: morales y patrimoniales}

Es al autor a quien, desde el momento mismo en que crea y exterioriza su creación, se le reconocen unos derechos en su calidad de tal ${ }^{13}$. Por su compleja configuración, dentro de tales derechos pueden distinguirse dos vertientes esenciales que se refieren a sendas prerrogativas a favor del creador de una obra: a) una vertiente o dimensión moral, donde se enmarcan los derechos morales 0 personales; b) una vertiente o dimensión patrimonial ${ }^{14}$.

Las facultades o atribuciones que conjuntamente otorgan ambas vertientes vendrían constituyendo aquello que se tutela con el derecho de autor. De forma sintética pasamos a comentar algunas de las principales características de cada uno de estos aspectos del derecho de autor:

\subsection{Derechos morales}

Se refiere al conjunto de facultades extrapatrimoniales con las que cuenta el creador de una obra del intelecto las cuales se orientan a proteger la paternidad del autor sobre la obra y, por lo tanto, a garantizar que la misma no sea divulgada o se afecte su integridad (que sea desfigurada o cambiada) sin que medie el consentimiento del autor ${ }^{15}$.

Estas facultades derivadas de la dimensión moral del derecho de autor son reconocidas en la doctrina como derechos de paternidad, de integridad, de

12 Corte Constitucional sentencia C-118 de 2005 MP, Clara Inés Vargas Hernández.

13 En nuestro ordenamiento jurídico no se exige registro o formalidad alguna para reconocer y proteger este derecho. Según lo estipulado en el artículo 193 de la ley 23 de 1982, el registro no cumple más que una finalidad de publicidad y "dar garantía de autenticidad y seguridad a los títulos de propiedad intelectual y a los actos y documentos que a ella se refieren."

14 Véase Corte Constitucional sentencia C- 1118 de 2005. MP. Clara Inés Vargas Hernández.

15 Normalmente, la vertiente moral se entiende configurada de esta manera; véase Fernando Miró LuInareS, La protección penal de la propiedad intelectual en la sociedad de la información, cit., p. 203; JuAn José González Rus, Bien jurídico protegido en los delitos contra la propiedad intelectual, cit., p. 757. 
divulgación, de modificación, de arrepentimiento y de acceso al ejemplar único ${ }^{16}$. En Colombia, Rengifo García presenta y explica como categorías del derecho moral: "derecho a la paternidad de la obra, derecho a la integridad de la obra, facultad de modificar la obra antes o después de su publicación, derecho de arrepentimiento y el derecho inédito"17.

La Corte Constitucional colombiana ha entendido que "Los derechos morales son aquellos que nacen como consecuencia de la creación misma y no del reconocimiento administrativo, son de carácter extrapatrimonial, inalienable, imprescriptible e irrenunciable"18. Estos derechos son independientes del contenido patrimonial y traen consigo los derechos a la divulgación, al reconocimiento de la paternidad intelectual, al respeto y a la integridad de la obra, y al retracto ${ }^{19}$. Cada uno de estos derechos implica, respectivamente, que el autor pueda decidir si conserva su obra inédita o la divulga; reivindicar la paternidad de la creación en cualquier momento ${ }^{20}$; modificar e impedir cualquier modificación o degeneración de la obra en todo momento; y, finalmente, retirar la obra del comercio o suspender cualquier forma en que se esté utilizando la misma, aunque para ello se hubiera contado con autorización. En suma, esta dimensión atribuye al autor la plena disposición de su obra ${ }^{21}$.

Cabe agregar que, según lo ha puesto de presente la Corte Constitucional, esta vertiente de contenido moral de los derechos de autor, como derecho personalísimo, es inalienable, irrenunciable, imprescriptible e independiente del contenido patrimonial ${ }^{22}$. Por los mismos motivos, el contenido moral se considera de rango fundamental en la medida en que surge de la condición misma de hombre ya que es al momento de crear, haciendo uso de su libertad, cuando el individuo manifiesta su personalidad y su ingenio. Por tanto, si se niega el derecho de autoría -dice la Corte- se le estará desconociendo

16 Juan José González Rus, Bien jurídico protegido en los delitos contra la propiedad intelectual, cit., p. 759.

17 Ernesto Rengifo García, Propiedad intelectual. El moderno derecho de autor, cit. pp.127-146.

18 Corte Constitucional, sentencia C-334 de 1993. MP. Alejandro Martínez Caballero

19 Ibíd.

20 De aquí que una de las características del derecho moral sea la perpetuidad (art. 30 de la Ley 23 de 1982, Ley de Derechos de autor, en adelante LDA). Con razón González Rus, señala: “En definitiva: tras la muerte del autor la perpetuidad del derecho moral se concreta en las facultades negativas de defensa de la paternidad del autor y de respeto a la integridad de la obra; desaparecen en cambio las positivas, con excepción de la divulgación, cuya duración se ve limitada a la fijada para los derechos de explotación", Juan José, González Rus, Bien jurídico protegido en los delitos contra la propiedad intelectual, cit., p. 761. Rengifo García por su parte explica: "La perpetuidad de las facultades morales significa que el control pos mortem auctoris de la paternidad e integridad de la obra corresponde a su cónyuge y herederos consanguíneos", cfr. ERnesto Rengifo García, Propiedad intelectual. El moderno derecho de autor, cit. p. 125. 
al hombre su condición de individuo racional que crea como manifestación de su propia naturaleza humana ${ }^{23}$.

También la Corte Suprema de Justicia se ha pronunciado sobre los derechos morales en sentido muy similar, así:

Las conductas que afectan el derecho moral de autor se relacionan con actos destinados a desconocer la paternidad de una obra cuando se le inscribe en el registro de autor con nombre de persona distinta del autor verdadero, o con título cambiado o suprimido, con el texto alterado, deformado, modificado o mutilado, o mencionado falsamente el nombre del editor o productor de la obra; de igual modo, con los actos que desconozcan la voluntad del autor de mantener inédita su creación, porque se publica total o parcialmente, sin su autorización expresa; y con comportamientos que atentan contra la integridad de la obra, cuando se compendia, mutila o transforma sin la expresa y previa autorización de su titular ${ }^{24}$.

\subsection{Derechos patrimoniales}

La dimensión patrimonial es aquella que atribuye al autor de la obra el derecho exclusivo a la explotación de la misma ${ }^{25}$. Este derecho comprende básicamente los derechos de reproducción, distribución (donde se incluirían, en nuestra opinión, los de exportación, importación o almacenaje) y comunicación pública, que son de carácter puramente económico ${ }^{26}$.

Al referirse al aspecto patrimonial, Rengifo García, explica: “Los derechos patrimoniales o derechos pecuniarios, o monopolios de explotación, como también se les llama, son un cúmulo de facultades exclusivas del autor que le permiten explotar por sí mismo su creación o autorizar su explotación por parte de terceros (...) El derecho de autor confiere al creador un monopolio de explotación de la obra como derecho exclusivo, absoluto y oponible erga omnes. Dicho derecho es transmisible, temporal y renunciable..." ${ }^{27}$. Los derechos patrimoniales implican, al menos, los siguientes derechos: disposición, reproducción, comunicación pública y derecho de transformación ${ }^{28}$.

La Corte Constitucional ha indicado que los derechos de explotación son aquellos mediante los cuales el autor busca obtener una remuneración por el uso que se llegue a hacer de su obra. Esta misma corporación también destaca que los derechos patrimoniales gozarán de protección constitucional a pesar de que no se

23 Véase Corte Constitucional, sentencia C- 155 de 1998, MP. Vladimiro Naranjo Mesa.

24 Corte Suprema de Justicia, sentencia 29188 del 30 de abril de 2008, MP. José Leonidas Bustos Ramírez.

25 Juan José González Rus, Bien jurídico protegido en los delitos contra la propiedad intelectual, cit., p. 757.

26 Cfr. Fernando Miró Luinares, La protección penal de la propiedad intelectual en la sociedad de la información, cit. pp. 198, 203 y 213.

27 Ernesto Rengifo García, Propiedad intelectual. El moderno derecho de autor, cit. p.157.

28 Ibíd. pp. 161-176. 
les reconozca el carácter de fundamentales ${ }^{29}$.

La Corte Suprema de Justicia, por su parte, en relación con la dimensión patrimonial de estos derechos ha dicho:

Por su parte, los comportamientos que atentan contra los derechos patrimoniales de autor, se relacionan con la explotación o utilización de la obra en formas no consentidas o deseadas por el autor o titular del derecho, en quien recae de manera exclusiva la facultad de enajenarla, cederla, autorizar o prohibir las reproducciones, modificarla, entre otros ${ }^{30}$.

La protección de estos derechos, por regla general, se entiende que rige durante toda la vida del autor y hasta ochenta años después de su muerte ${ }^{31}$, y se encuentran regidos por el principio de autonomía de la voluntad y son renunciables ${ }^{32}$. En tal medida, el autor no sólo podrá determinar la disponibilidad de los derechos patrimoniales sobre su obra, sino que también podrá explotarla económicamente y controlar (brindando o no su autorización) los posibles actos de explotación que sobre aquella recaigan.

El titular de estos derechos patrimoniales puede entonces ser tanto el autor como la persona natural o jurídica a quien se hayan transferido aquéllos ${ }^{33}$. Así, estos derechos pertenecen originariamente al autor o creador de la obra para que se beneficie de las utilidades económicas que arroje su creación, si bien los terceros podrán ejercer los mismos derechos cuando medie autorización del autor ${ }^{34}$. Lo anterior comporta una gran trascendencia penal, puesto que implica -como se verá más adelante- que el consentimiento del autor conllevará la atipicidad del hecho ${ }^{35}$.

Cabe anotar que la distinción entre vertiente moral y patrimonial ha sido objeto de discusión, en la medida en que algunos entienden que una tal concepción dualista supone una distinción irreal o artificial y en consecuencia sostienen una posición monista, que los lleva a plantear que entre ambos contenidos existe una interconexión tal que su separación es, en todo caso, poco menos que imposible. En tal sentido, puesto que configuran un solo derecho, debe presentarse siempre una protección conjunta de ambas dimensiones.

Sin referirse expresamente a la discusión sobre el monismo o el dualismo, la Corte Suprema de Justicia reconoce en la legislación penal colombiana una postura

29 Corte Constitucional Sentencia T-367 de 2009. MP. Jorge Iván Palacio Palacio.

30 Corte Suprema de Justicia, sentencia 29188 del 30 de abril de 2008, MP. José Leonidas Bustos Ramírez.

31 Artículo 2 de la ley 44 de 1993 que modifica el artículo 29 de la ley 23 de 1982.

32 Juan José González Rus, Bien jurídico protegido en los delitos contra la propiedad intelectual, cit., p. 762.

33 Sobre las modalidades de transmisión véase Decisión 351 de la Comunidad Andina de Naciones, Régimen Común sobre Derecho de Autor y Derechos Conexos, Cap. IX.

340 cuando lo permita la ley, según lo estipulan las demás leyes en el ordenamiento al respecto. 
dualista, al afirmar que: "El nuevo código penal, como se indicó en precedencia, escinde las diversas formas de delitos contra los derechos de autor (violación a los derechos morales, patrimoniales y a los mecanismos de protección), que en las legislaciones precedentes se entremezclaban" ${ }^{36}$. En opinión de la misma Corte, la forma de regulación supone una mejor técnica legislativa, con lo cual, es claro que al menos implícitamente, adopta una posición dualista sobre el tema. En cuanto a la doctrina colombiana, por lo menos en el ámbito jurídico-penal, no parece haber tenido, por lo menos hasta ahora, mucho eco esta discusión.

En la doctrina extranjera, en particular la española, la doctrina se divide entre monistas y dualistas. Así por ejemplo, González Rus ${ }^{37}$ adopta postura monista, argumentando que la relación entre derechos patrimoniales y morales de autor es tan estrecha que le resulta artificial sostener que ambos son derechos independientes y autónomos. Siendo un único derecho, dice este autor, si el mismo se afecta ello incidirá en todas las facultades que lo conforman. Un buen ejemplo de ello es el derecho de divulgación, "(...), que, aún reconocido como derecho moral, incide en los derechos de reproducción o distribución de la obra, posibilitando su explotación económica"38.

Por otro lado, uno de los defensores de la postura dualista es Miró Llinares, quien plantea que es ineludible (particularmente en la legislación española) distinguir entre los derechos morales y patrimoniales de autor, puesto que ambos cuentan con un contenido, unas características y un régimen jurídico diferente. Al respecto el citado autor se plantea:

(...), los derechos de reproducción, distribución y comunicación pública exclusiva se conceden al intérprete 0 artista ejecutante sobre la ejecución de su obra, a los productores fonográficos y audiovisuales, a las entidades de radiodifusión, entre otros. Por tanto, la realización de estos comportamientos típicos afecta directamente a los intereses económicos del autor, del cesionario o del titular de un derecho conexo. ¿Afectan a los intereses morales del autor? Al ser estos derechos patrimoniales de explotación exclusiva de contenido, régimen y fundamento distinto al de los derechos morales de autor, su infracción no tiene por qué suponer la lesión de un derecho moral (aunque en ocasiones sea así), puesto que puede explotarse la obra sin permiso del cesionario pero respetando la integridad de la misma, la paternidad del autor y todos los demás del autor (y hasta el de la "primera divulgación", si ya no es inédito). De hecho, en la piratería, comportamiento principal lesivo de los derechos patrimoniales, en la mayoría de las ocasiones se respeta la paternidad del autor: simplemente se efectúa una explotación sin permiso no del autor, que normalmente ha cedido el derecho, sino del editor o productor. Por tanto, la incriminación de las conductas de reproducción, distribución y comunicación pública supone la protección única del derecho de explotación del autor sobre su obra ${ }^{39}$.

36 Corte Suprema de Justicia, sentencia 29188 del 30 de abril de 2008, MP. José Leonidas Bustos Ramírez.

37 Juan José González Rus, Bien jurídico protegido en los delitos contra la propiedad intelectual, cit., p. 758.

38 Ibíd., p. 758

39 Fernando Miró Lunares, La protección penal de la propiedad intelectual en la sociedad de la información, cit., p. 211. 
Adicionalmente, y para el caso de la legislación penal, debe decirse que en todo caso, que aunque el artículo 270 del código penal hace referencia a "violación a los derechos morales de autor", y el artículo 271 se titula "defraudación a los derechos patrimoniales de autor", ello no es criterio determinante para afirmar, sin más, que se pueda sostener una concepción dualista, al menos en forma pura, y ello debido en el mismo código penal a veces nos encontramos con eventos en los que al parecer se protege la dimensión moral, pero que necesariamente, al tiempo también se puede estar protegiendo la vertiente patrimonial. Así, el por ejemplo, se encuentra en que el artículo 270 (que se supone corresponde a los derechos morales) alude a la transformación de la obra, a pesar de que este último derecho suele ser visto por algunos como una facultad patrimonial, como es el caso de Rengifo García, para quien el derecho de transformación "es esencialmente una facultad patrimonial en virtud de la cual el autor tiene la atribución exclusiva de autorizar la explotación de la obra transformada"40.

\section{Bien jurídico: ¿individual o colectivo?}

Una dificultad que se encuentra al momento de delimitar el bien jurídico en los delitos contra los derechos de autor tiene que ver con la discusión acerca de si los mismos pueden ser o no encuadrados como delitos socioeconómicos y si la clase de intereses protegidos por los mismos son de carácter individual o colectivo ${ }^{41}$. Con el único propósito de dejar ilustrada una de las aristas de la discusión y sin entrar a profundizar en el problema, que será objeto de un trabajo posterior, podemos señalar lo siguiente:

En sentido estricto, se ha planteado que los delitos socioeconómicos se refieren a la "infracción jurídico-penal que lesiona o pone en peligro el orden económico, entendido como regulación jurídica del intervencionismo estatal en la economía de un país"42. Y en un sentido amplio se sostienen dos enfoques: primero, que el delito económico consiste en la "infracción que, afectando a un bien jurídico patrimonial individual, lesiona o pone en peligro, en segundo término, la regulación de la producción, distribución y consumo de bienes y servicios, esto es, el orden económico entendido en sentido amplio"43. El segundo enfoque es el defendido por Martínez-Buján, quien señala:

(...) la concepción amplia aquí propugnada permite extender la noción a delitos que no poseen un bien jurídico supraindividual como objeto inmediato

\footnotetext{
40 Ernesto Rengifo García, Propiedad intelectual. El moderno derecho de autor, cit. p.173.

41 Fernando Miró Luinares, La protección penal de la propiedad intelectual en la sociedad de la información, cit., pp. 207-208

42 Miguel Bajo Fernández/Silvina bacigalupo, Derecho penal económico, cit., p. 14, citado por Fernando Miró Llinares, La protección penal de la propiedad intelectual en la sociedad de la información, cit., p. 224.

43 Ibíd, p. 225.
} 
de protección, sino que se trata de delitos que tutelan directamente un bien jurídico individual de contenido económico, pero con la particularidad de que se orientan a la protección de un bien jurídico mediato supraindividual, o si se prefiere, se caracterizan por el hecho de que entre otros motivos o razones que influyen en la decisión del legislador de otorgarles rango penal se cuenta la existencia de intereses colectivos o supraindividuales necesarios para un correcto funcionamiento del sistema económico imperante ${ }^{44}$.

Partiendo de un concepto muy amplio de los delitos socioeconómicos se ha discutido si lo delitos contra la propiedad intelectual hacen parte de delitos económicos y de la empresa, y por tanto, estarían involucrados bienes jurídicos colectivos. Cabe resaltar sin embargo, que por lo menos en la doctrina española la balanza parece inclinarse por la idea de que se trata de intereses individuales ${ }^{45}$.

Refiriéndose a los derechos de autor, en Colombia, Gaviria Londoño, sostiene:

(...) lo que se protege con los tipos penales del capítulo VIII del libro $2^{\circ}$ del Código Penal es la preservación del equilibrio que debe existir entre el interés privado de los autores, intérpretes, productores fonográficos, entre otros. y el interés público y social de acceder en condiciones justas y de competencia leal al disfrute de todas aquellas manifestaciones en que se concreta la creación del intelecto ${ }^{46}$.

También hay quienes entienden que los delitos contra los derechos de autor al proteger la creación están orientados a tutelar de algún modo un interés cultural de carácter colectivo.

Por nuestra parte estamos de acuerdo con Martínez-Buján cuando acertadamente señala:

En cambio, parece muy discutible la incardinación de los delitos relativos a la propiedad intelectual en el seno del grupo acabado de analizar. Según puse ya anteriormente de relieve, de forma sorprendente el legislador de 1995 rescató para el capítulo XI la presencia de esta familia delictiva, sin que esa solución se contemplase en los restantes textos prelegislativos (...), ni siquiera en el propio Proyecto de 1994. Y es que, desde la perspectiva de su orientación material, tales delitos en modo alguno pueden ser reconducidos al Derecho penal de la “competencia económica" y, en todo caso, muy poco tienen en común con éste ${ }^{47}$.

Y en el mismo sentido con González Rus, quien al comentar el artículo 270 del código penal español, sostiene: "Con todo, el sentido real de estos delitos, es, a mi

44 Carlos Martínez-Buján Pérez, Derecho penal económico. Parte general, Valencia, 1998, p. 59.

45 Al respecto véase Fernando Miró Llinares, La protección penal de la propiedad intelectual en la sociedad de la información, cit., pp. 221-233.

46 Vicente E Gaviria Londoño, "Delitos contra los derechos de autor", cit. p. 549.

47 Carlos Martínez-Buján Pérez, Derecho penal económico. Parte general, cit., p. 76. 
juicio, eminentemente patrimonial, sin que el art. 270 ofrezca elementos que permitan ver en su contenido una orientación a la tutela de intereses generales o una naturaleza predominantemente socioeconómica"48.

El mismo autor agrega, algo que a nuestro juicio, mutatis mutandi, se puede predicar también en relación con el código penal colombiano, esto es que: “En la regulación de los delitos relativos a la propiedad intelectual predomina la perspectiva concreta del creador y la explotación económica de la obra, lo que evidencia que la protección se aborda prescindiendo de dimensiones más generales..."49.

En este orden de ideas, si se observa la concreta regulación de los derechos de autor en los artículos 270 y 271 del código penal colombiano, puede afirmarse como lo hace González Ruz para el caso español, que el bien jurídico protegido tiene una naturaleza individual, pues se advierte un predominio de la perspectiva del autor. Un bien jurídico que cuenta, por un lado, con una dimensión moral, entendida como el conjunto de facultades extrapatrimoniales con las que cuenta el creador de una obra del intelecto; y, por otro lado, con una dimensión patrimonial, que se corresponde con los derechos de explotación sobre la obra. Una tal concepción del bien jurídico, a nuestro entender puede ser avalada también con base en la jurisprudencia de la Corte Suprema de Justicia ${ }^{50}$.

\section{Algunos aspectos relevantes relacionados con la interpretación de los artículos 270 y $271^{51}$}

Antes de exponer posibles interpretaciones del contenido típico de los artículos 270 y 271 C.P., es importante advertir que los mismos recogen muchos y muy diversos

48 Juan José González Rus, Bien jurídico protegido en los delitos contra la propiedad intelectual, cit., pp. $769-770$

49 Ibíd. p. 770.

50 Que se trata de un bien jurídico de naturaleza individual también parece ser lo que entiende la Corte Suprema en la sentencia cuando se refiere a que "el bien jurídico que se tutela en el tipo específico del artículo 271-1 del Código Penal (54-4 L.44/93), es el derecho patrimonial de autor, en virtud del cual ejerce actos de explotación o de disposición de la obra, es decir, actividades que envuelven contenido económico, valorables pecuniariamente..",véase Corte Suprema de Justicia, sentencia 29188 del 30 de abril de 2008, MP. José Leonidas Bustos Ramírez.

51 Para complementar o interpretar más adecuadamente estas normas y de manera que su interpretación resulte coherente con el ordenamiento, debe tenerse en cuenta regulación extrapenal vigente en la materia. Destacamos como principales: arts. 7, 25, 58, 61, 70 y 72 C.N, Artículo 671 del código civil, Ley 23 de 1982, Ley 44 de 1993, Ley 603 de 2000, Ley 1032 de 2006, Decreto 1360 de 1989, Decreto 2041 de 1991, Decreto 460 de 1995, Decreto 162 de 1996, Decreto 1278 de 1996, Decreto 4540 de 2006; además de un buen número de convenios internacionales sobre derechos de autor y conexos ratificados por Colombia. La Dirección Nacional de Derecho de Autor ofrece en su página web (http:// www.derautor.gov.co/htm/legal/legislacion/constitucion.htm) una completa lista con la regulación vigente al respecto. 
comportamientos que dificultan su explicación y sistematización. Buscando acotar esta dificultad, se presentarán en primer lugar algunas definiciones, para luego presentar algunas observaciones sobre la concreta regulación legal de estos delitos.

Siguiendo el esquema empleado Gaviria Londoño ${ }^{52}$ haremos referencia a algunos conceptos relativos a las creaciones protegidas cuya definición está dada por otras normas de nuestro ordenamiento:

a) Obras artísticas, científicas y literarias

(...) libros, obras musicales, pinturas al óleo, a la acuarela o al pastel, dibujo, grabados en madera, obras caligráficas y crisográficas, obras producidas por medio de corte, grabado, damasquinado, entre otros., de metal, piedra, madera u otros materiales, estatuas, relieves, esculturas, fotografías artísticas, pantomimas, u otras obras coreográficas. (Art. 8 lit. A, Ley 23 de 1982).

b) Obra audiovisual

(...) toda creación expresada mediante una serie de imágenes asociadas, con o sin autorización incorporada, que esté destinada esencialmente a ser mostrada a través de aparatos de proyección o cualquier otro medio de comunicación de la imagen y de sonido, independientemente de las características del soporte material que la contiene ${ }^{53}$.

Acá se incluyen, por ejemplo, documentales, cortometrajes, largometrajes y programas de televisión.

c) Emisión o transmisión

"la difusión por medio de ondas radioeléctricas, de sonido o de sonidos sincronizados con imágenes." (Art. 8 lit. Ñ, Ley 23 de 1982).

d) Obra musical

Se trata de obras expresadas mediante la combinación de sonidos (composición), con 0 sin texto (letra o guión).

e) Obra inédita

"aquella que no haya sido dada a conocer al público" (Art. 8 lit. G, Ley 23 de 1982).

f) Obra cinematográfica

"cinta de video y videograma: la fijación, en soporte material, de sonidos sincronizados con imágenes, 0 de imágenes sin sonido." (Art. 8 lit. S, Ley 23 de 1982).

g) Fonograma

"la fijación, en soporte material, de los sonidos de una ejecución o de otros sonidos" (Art. 8 lit. M, Ley 23 de 1982).

52 Vicente E. Gaviria Londoño, Delitos contra los derechos de autor, cit., pp. 559- 560.

53 Cfr. Decisión 351 de la Comunidad Andina de Naciones, Régimen Común sobre Derecho de Autor y Derechos Conexos, art. 3. 
h) Programas de ordenador o soporte lógico (software)

(...) expresión de un conjunto de instrucciones mediante palabras, códigos, planes 0 en cualquier otra forma que, al ser incorporadas en un dispositivo de lectura automatizada, es capaz de hacer que un ordenador -un aparto electrónico o similar capaz de elaborar informaciones- ejecute determinada tarea u obtenga determinado resultado. El programa de ordenador comprende también la documentación técnica y los manuales de uso. (Art. 2, Decisión 351 de la Comunidad Andina de Naciones, Régimen Común sobre Derecho de Autor y Derechos Conexos).

Teniendo presente las anteriores definiciones, podemos pasar ahora a comentar algunos aspectos a nuestro modo de ver relevantes 0 al menos problemáticos en relación con los mencionados artículos 270 y 271 del código penal. Veamos:

\subsection{Artículo 270 C.P.}

Incurrirá en prisión de dos (2) a cinco (5) años y multa de veinte (20) a doscientos (200) salarios mínimos legales mensuales vigentes quien:

270 \#1. Publique, total o parcialmente, sin autorización previa y expresa del titular del derecho, una obra inédita de carácter literario, artístico, científico, cinematográfico, audiovisual o fonograma, programa de ordenador o soporte lógico.

En este numeral se alude a la publicación entendida, según nuestra opinión, como la difusión por cualquier medio (por ejemplo, la imprenta) de alguna de las obras que este numeral dispone. Esta descripción no especifica que, para ser punible, dicha publicación deba hacerse negando el verdadero autor de la obra, de aquí que se entienda que la conducta penalizada sea la mera publicación no autorizada de la obra inédita. Y ello tiene sentido en la medida en que existe un derecho moral denominado por la doctrina, derecho al inédito, según el cual el autor tiene derecho a conservar su obra inédita hasta su fallecimiento o después de él ${ }^{54}$.

No obstante, en relación con este asunto, se proponen opciones interpretativas distintas, como es el caso de Gaviria Londoño, quien al respecto afirma: "A pesar de lo anterior, creemos que, si bien puede entenderse que en el numeral I del artículo 270 se sanciona la violación al derecho al inédito, es lo cierto que el principal derecho moral de autor es el que le permite a quien ostenta tal calidad reivindicar en todo tiempo la paternidad de su obra, resultando un contrasentido que el legislador hubiera dejado sin protección penal dicho derecho, por lo que pensamos que al hablarse de publicación de la obra ajena se está haciendo referencia a la forma

54 Cfr. Ernesto Rengifo García, Propiedad intelectual. El moderno derecho de autor, cit. pp.145-146., quien al respecto afirma: "Si bien con la divulgación la obra deviene un bien patrimonial, antes de la divulgación la obra forma parte de la personalidad del autor. Esta es la razón por la cual el derecho al inédito es una facultad personal comprendida dentro del concepto del derecho moral. El derecho al inédito, por consiguiente, se presenta como una manifestación negativa del derecho patrimonial". 
más frecuente en que puede tener lugar la ilícita apropiación de la obra de otro"55.

270 \#2. Inscriba en el registro de autor con nombre de persona distinta del autor verdadero, o con título cambiado o suprimido, o con el texto alterado, deformado, modificado o mutilado, o mencionando falsamente el nombre del editor o productor de una obra de carácter literario, artístico, científico, audiovisual o fonograma, programa de ordenador 0 soporte lógico.

Creemos que en este numeral se busca proteger el derecho a la paternidad y a la integridad de la obra ${ }^{56}$. La paternidad supone que "el autor tiene derecho a reivindicar en cualquier tiempo la paternidad de su obra y, en especial, a que se indique su nombre o seudónimo, cuando ella se reproduzca o sufra cualquier transformación (traducción adaptación, arreglo), o se comunique al público mediante interpretación, ejecución, radiodifusión o cualquier otro medio conocido o por conocer." ${ }^{\text {57 }}$ Mientras que el derecho a la integridad de la obra implica la posibilidad de "oponerse a toda deformación, mutilación o modificación que atente contra el decoro de la obra o la reputación del autor" ${ }^{\prime \prime}$.

A diferencia del anterior, este numeral no limita la protección a las obras inéditas, con lo cual la interpretación y aplicación de esta descripción típica protege más ampliamente la paternidad aunque no sea más que en lo relativo a la inscripción de la obra. Cabe resaltar además que en este numeral, tal como se sigue de su literalidad, se protegen no sólo los derechos del autor, sino también los derechos conexos del editor o productor ${ }^{59}$.

270 \#3. Por cualquier medio o procedimiento compendie, mutile o transforme, sin autorización previa o expresa de su titular, una obra de carácter literario, artístico, científico, audiovisual o fonograma, programa de ordenador o soporte lógico.

En este caso se hace referencia a los actos de modificación o deformación de una creación, aquí se incluirían, por ejemplo, las posibles traducciones de la obra, en línea con el derecho a la integridad de la misma consagrado en el artículo 30 lit. B de la Ley 23 de 1982. No obstante, en la interpretación de este numeral no puede perderse de vista el principio de lesividad, de manera que deberá tenerse presente que

55 Vicente E. Gaviria Londoño, Delitos contra los derechos de autor, cit., p. 561.

56 Vicente E. Gaviria Londoño, Delitos contra los derechos de autor, cit., pp. 561-562, critica esta disposición por considerar que "confunde una serie de conductas que en principio parecerían ser excluyentes", no obstante, llega a la conclusión de que se protege la paternidad en la medida en que afirma que: "con la disposición del numeral 2 del artículo 270 del C.P. es posible sancionar la conducta de quien, así no publique la obra inédita o publicada ajena, la inscribe como propia en la Oficina de Registro de Derechos de Autor."

57 Cfr. Ernesto Rengifo García, Propiedad intelectual. El moderno derecho de autor, cit. p. 127.

58 Ibid. p. 131

59 Vicente E. Gaviria Londoño, Delitos contra los derechos de autor, cit., p. 562 
las modificaciones no autorizadas serán punibles sólo en la medida en que demeriten la obra o afecten la reputación o los intereses legítimos del titular del derecho ${ }^{60}$.

Teniendo en cuenta que este tercer numeral no se pronuncia acerca del momento en que debe tener lugar la conducta, se entiende que la modificación no autorizada será punible tanto si se realiza antes de la publicación como si se presenta luego de la misma.

El artículo 270 contiene un parágrafo, cuya redacción puede inducir a confusión Es el siguiente:

Parágrafo. Si en el soporte material, carátula o presentación de una obra de carácter literario, artístico, científico, fonograma, videograma, programa de ordenador 0 soporte lógico, u obra cinematográfica se emplea el nombre, razón social, logotipo o distintivo del titular legítimo del derecho, en los casos de cambio, supresión, alteración, modificación o mutilación del título o del texto de la obra, las penas anteriores se aumentarán hasta en la mitad.

A nuestro modo de ver, la circunstancia agravante consignada en este parágrafo resulta aplicable al numeral 1 en la medida en que se entienda que en dicho numeral se protege el derecho al inédito y que por tanto si además de publicar la obra inédita sin autorización de su titular y por tanto violando este derecho, se mutila la obra (p. ej. cambia el título o se altera el texto de la misma) esta conducta tendrá un desvalor adicional, consistente en afectar con ello la reputación del autor o demeritar la obra ${ }^{61}$.

En cuanto al numeral 2, estamos de acuerdo con Gaviria Londoño cuando sostiene que el parágrafo es inaplicable a este numeral, en la medida en que resultaría contradictorio que si el numeral 2 sanciona el que se registre la obra con una calidad que no se ostenta, al mismo tiempo pueda mencionarse en el acto de registro el nombre del autor en la carátula o en el soporte material de la obra deformada o mutilada. ${ }^{62}$ En efecto, si en ningún momento se hace pública la verdadera titularidad, como parece ser el caso del art. 270-2 C.P., difícilmente se afectará la reputación del titular pero seguirá siendo posible que se demerite la obra.

En relación el numeral 3, consideramos que el parágrafo no ofrece problema para ser aplicado en las hipótesis allí contempladas, dado que si las modificaciones a la obra tienen relevancia penal cuando afectan la reputación o los intereses legítimos del titular del derecho, ello más probablemente se presentará cuando se reconozca quién es este último, por lo cual una modificación de la obra bajo el nombre de su creador podrá resultar ser más lesivo para los derechos de autor de éste ${ }^{63}$.

60 En igual sentido ibid., p. 563.

61 De otra opinión, Gaviria Londoño, que considera inaplicable el parágrafo a los numerales 1 del art. 270. cfr. ibíd. p. 564

62 Ibíd. p. 564

63 Además, como lo anota Gaviria Londoño, con la conducta que se adecue a este parágrafo se estarían 


\subsection{Artículo 271 C.P.}

Violación a los derechos patrimoniales de autor y derechos conexos. Modificado por la Ley 1032 de 2006. Incurrirá en prisión de cuatro (4) a ocho (8) años y multa de veintiséis punto sesenta y seis (26.66) a mil (1.000) salarios mínimos legales mensuales vigentes quien, salvo las excepciones previstas en la ley, sin autorización previa y expresa del titular de los derechos correspondientes.

A efectos de analizar algunos aspectos relacionados con la violación de los derechos patrimoniales de autor, conviene tener en consideración lo dicho por la Corte Suprema en relación con el art. 271-1, en el sentido de exigir para la configuración del delito, el ánimo de lucro:

(... de) manera que quien pretenda afectarlos ha de obrar con ánimo de lucro y con la intención de lesionar ese patrimonio en beneficio propio o de terceros.

Si bien estas exigencias no se encuentran expresamente consignadas en la norma prohibitiva, constituyen verdaderos elementos subjetivos del tipo que en cada caso han de ser constatados por el juez, en orden a declarar demostrada, en grado de certeza, la materialidad de la conducta ${ }^{64}$.

En general, y con las debidas precisiones que en cada caso concreto deben hacerse, consideramos que este ánimo de lucro ha de estar presente, para que se configure el tipo, en todas las conductas descritas en este artículo.

271 \#1. Por cualquier medio o procedimiento, reproduzca una obra de carácter literario, científico, artístico o cinematográfico, fonograma, videograma, soporte lógico o programa de ordenador, o, quien transporte, almacene, conserve, distribuya, importe, venda, ofrezca, adquiera para la venta o distribución, 0 suministre a cualquier título dichas reproducciones.

Este primer numeral es quizás el más representativo de las conductas que afectan los derechos patrimoniales de autor, en particular la conducta consistente en la reproducción de la obra con fines de lucrarse económicamente de la misma. Además de la reproducción aparecen como verbos rectores el almacenar, conservar, distribuir, importar, vender, ofrecer, adquirir para la venta, conductas todas, que según lo hemos dejado expresado más arriba, deben realizarse el ánimo de lucro.

simultáneamente defraudando los derechos patrimoniales, "(...), pues que en la disposición en cita claramente se alude a la inclusión del nombre del autor verdadero, por manera que se reconoce a éste en su condición de tal, y precisamente se utiliza el mismo para lucrarse ilícitamente de su creación."; No obstante a renglón seguido afirma: "Con todo puede ofrecerse una interpretación Diferente según la cual el evento a que se refiere el parágrafo del artículo 270 del C.P. no constituye un evento de plagio pero sí dice relación con una violación a los derechos morales de autor, pues entre éstos se encuentra la facultad de impedir que se efectúen mutilaciones, transformaciones y compendios de la obra" Ibíd. cit., pp. 551-552 
Mención aparte merece el verbo suministrar, previsto en la parte final del numeral 1 del art.270, en la medida en señala que el mismo puede realizarse a cualquier título, no obstante, consideramos que en cada caso deberá acreditarse que ese suministro estaba dirigido a fines lucrativos -a favor de quien hace el suministro 0 de un tercero-, pues de lo contrario la conducta no debería ser objeto de sanción penal por cuanto la ausencia de tal finalidad lucrativa implicaría, según creemos, una ausencia de lesividad para los derechos patrimoniales que se pretenden proteger con la prohibición.

Una problemática interesante en relación con este tipo es la posibilidad de que se presente un concurso entre los artículos 270-1 y el 271-1. Sobre este particular estamos de acuerdo con Gaviria Londoño cuando afirma que se trataría tan solo de un concurso delictivo aparente entre plagio y piratería ${ }^{65}$, que debe resolverse a favor del plagio, cuya sanción busca la protección del derecho moral a la paternidad de la obra. .No obstante lo anterior, parece más discutible que la solución sea la misma en aquellas hipótesis en que se publique una obra inédita sin autorización de su titular y que además se comercialice. Con la primera actuación se viola el derecho moral al inédito y con la segunda el derecho de explotación de la obra por medio de su comercialización. Luego parecería que se trata de dos conductas sucesivas, la publicación y la subsiguiente comercialización, que darían lugar a dos tipicidades distintas, en las cuales se pueden distinguir dos intereses jurídicos distintos, ambos protegidos penalmente.

271 \#2. Represente, ejecute 0 exhiba públicamente obras teatrales, musicales, fonogramas, videogramas, obras cinematográficas, o cualquier otra obra de carácter literario 0 artístico.

Este segundo numeral sigue la línea del anterior, sólo que en esta ocasión lo que se pretende es prohibir la conducta consistente en lucrarse sin autorización de la presentación pública de la obra. 0 , dicho de otro modo, presentar al público la obra (teatral, musical, fonograma, entre otros.) evadiendo el pago de los derechos patrimoniales que corresponden a los titulares.

271 \#3. Alquile 0, de cualquier otro modo, comercialice fonogramas, videogramas, programas de ordenador o soportes lógicos u obras cinematográficas.

Al parecer, este numeral no estipula cosa distinta, en lo esencial, a lo consagrado por el numeral 1 de este mismo artículo, agregando tan sólo el que se comercialice de cualquier modo, lo cual no supone tampoco una gran diferencia si se tiene en cuenta que en tal numeral 1 se consignan también otras formas de comercialización, como es el caso de la venta. 
No obstante, Gaviria Londoño sostiene que lo que en este numeral se sanciona, "no es la reproducción ilícita de una obra ajena o el manejo o suministro a cualquier título de una obra "pirata", sino que se reprime la conducta de quien comercializa de cualquier modo una obra ya publicada, sin obtener permiso previo y expreso para ello, con lo cual desconoce el derecho de explotación del titular de los derechos" ${ }^{\prime \prime 6}$.

El mismo autor plantea que en esta disposición cabría la hipótesis en que alguien, por ejemplo, comprara el original de una obra (lo cual le otorgaría sólo el derecho de reproducirla en privado) y lo ofreciera luego en alquiler. Esta interpretación lo que sugiere es que, como se ha venido indicando, cada una de las manifestaciones del derecho de explotación es independiente, se encuentra sujeto a una regulación especial y requiere la autorización del titular del mismo.

271 \#4. Fije, reproduzca o comercialice las representaciones públicas de obras teatrales o musicales.

Este cuarto numeral, en la misma línea del numeral anterior, lleva a entender que cada manifestación derecho de explotación debe ser autorizado independientemente de los demás. Así, puede encontrarse que alguien fue autorizado para presenciar 0 incluso para fijar ${ }^{67}$ una representación pública de las que menciona esta disposición, mas no por ello tendrá también derecho a reproducirla o comercializarla.

Sin embargo, consideramos que la mera fijación, aunque no esté autorizada, en principio solo representa un peligro potencial para el derecho patrimonial y si tal conducta no está acompañada de una finalidad lucrativa, habría que concluir que la fijación, sin más, no puede considerarse delictiva, pues carecería de lesividad y en todo caso, su sanción supondría una inaceptable anticipación del ámbito de lo punible en esta materia.

271 \#5. Disponga, realice o utilice, por cualquier medio o procedimiento, la comunicación, fijación, ejecución, exhibición, comercialización, difusión 0 distribución y representación de una obra de las protegidas en este título.

Si en el numeral anterior se sancionaba la fijación reproducción o comercialización de representaciones públicas, en este numeral 5 lo que se aprecia es una ampliación de las conductas, en tanto que incluye además la ejecución, exhibición, difusión y distribución no solo de representaciones públicas de obras teatrales 0 musicales, sino de cualquiera otra obra de las mencionadas en el título (p. ej. una obra literaria, fonograma, videograma, entre otros).

En nuestra opinión es que la separación que se hace en los dos numerales

66 Vicente E. Gaviria Londoño, Delitos contra los derechos de autor, cit., p. 567.

67 La ley 23 de 1982, en su art. $8^{0}$ lit. R define fijación como: "incorporación de imágenes y/o sonidos sobre una base material suficientemente permanente 0 estable para permitir su percepción, reproducción 0 comunicación." 
induce a confusión al intérprete, y quizá convendría unificar en un solo numeral estas conductas con una redacción más precisa.

Especial mención merece el verbo disponer uno de cuyos significados es según el diccionario Real Academia Española significa "Deliberar, determinar, mandar 10 que ha de hacerse". En este sentido, consideramos que este verbo rector tendría aplicación en los casos en los que un sujeto es el que determina o manda lo que debe hacerse y es otro el que lo realiza, caso en el cual la responsabilidad penal solo recaería sobre el primero. Por ejemplo, el director o dueño de una sala de cine dispone la exhibición para el público de una película respecto de la cual no ha pagado los derechos correspondientes. Si bien quien realiza materialmente la exhibición es un empleado de la sala de cine, es sobre el director o dueño sobre el que recae la responsabilidad, pues es el a quien corresponde la obligación de pagar los derechos o contando en todo caso, con la debida autorización para así poder disponer lícitamente su exhibición pública.

271 \#6. Retransmita, fije, reproduzca 0, por cualquier medio sonoro o audiovisual, divulgue las emisiones de los organismos de radiodifusión.

Si bien parce claro que en abstracto las conductas descritas en este numeral son idóneas para vulnerar los derechos patrimoniales del correspondiente titular debe tenerse cuidado en cada caso concreto de determinar su efectiva lesividad. Así por ejemplo, podría encajar en esta descripción típica el comportamiento de quien graba (como frecuentemente sucede), para uso privado y sin fines comerciales, la serie televisiva de su preferencia ${ }^{68}$. En un caso así, no parece estar justificado que la mera fijación implique consigo una lesión de los derechos de explotación del autor de la obra que permitiera justificar la intervención penal.

Importa destacar que aquí se protegen derechos conexos de divulgación que corresponden al organismo de radiodifusión.

271 \#7. Recepcione, difunda o distribuya por cualquier medio las emisiones de la televisión por suscripción.

Puede repetirse en este numeral lo dicho en relación con el anterior pues en este se pretende sancionar penalmente la recepción de canales de televisión sin la debida suscripción. Hay quienes consideran además que esta disposición incorpora un casuismo exagerado que hace difícil la inteligibilidad de la norma ${ }^{69}$.

68 Recuérdese que, como lo estipula la Ley 23 de 1.982 en su Art. $8^{\circ}$ lit. ñ, la radiodifusión no hace referencia sólo a las emisiones de la radio, sino a "la difusión por medio de ondas radioeléctricas, de sonido o de sonidos sincronizados con imágenes"; de acuerdo con lo anterior, la misma ley señala en su Art. $8^{0}$ lit. $\mathrm{N}$, que un organismo de radiodifusión es "la empresa de radio o televisión que transmite programas al público." Garivira Londoño, también considera que la sanción puede resultar desproporcionada y pone como ejemplo el caso de alguien que grabe canciones transmitidas por radio, cit. p. 569. 


\section{8. ¿Convendría la unificación de la regulación penal?}

El casuismo que se encuentra en las disposiciones analizadas, así como la dificultad de hacer una distinción tajante y definitiva en relación con la violación de los derechos morales y patrimoniales de autor, podría hacer aconsejable la unificación en un solo artículo de las conductas lesivas para ambos derechos (morales y patrimoniales), como ocurre por ejemplo en la legislación española. Allí el artículo 270 del código penal vigente, recoge las conductas relativas a la violación de la propiedad intelectual con una redacción a nuestro juicio más simplificada que quizás evitaría los problemas interpretativos que las actuales disposiciones en el código penal colombiano plantean.

\section{Bibliografía}

Bajo Fernández, Miguel Y Bacigalupo, Silvina, Derecho penal económico, Madrid, Editorial Centro de Estudios Ramón Areces, S.A, 2.001.

Cobo del Rosal, Manuel, Compendio de Derecho Penal Español, Madrid- Barcelona, Marcial Pons, Ediciones Jurídicas y Sociales, S.A., 2000

García Rengifo, Ennesto Propiedad intelectual. El moderno derecho de autor, Bogotá, Universidad Externado de Colombia, 1997

Gaviria Londoño, Vicente E:: Delitos contra los derechos de autor, en "Lecciones de derecho penal. Parte especial.", Bogotá, Universidad Externado de Colombia, 2003.

González Rus, JuAn José, “Bien jurídico protegido en los delitos contra la propiedad intelectual, en El nuevo código penal: presupuestos y fundamentos. Libro homenaje al Profesor Doctor Don Ángel Torío López, Granada, 1999,

Martínez-Buján Pérez, C.: Derecho penal económico. Parte general, Valencia, 1998.

Miró Llinares, Fernando, La protección penal de la propiedad intelectual en la sociedad de la información, Madrid, Editorial Dykinson S.L Meléndez Valdés

Rey Vega, Carlos: La propiedad intelectual como bien inmaterial, Bogotá, Leyer, 2005. 